\title{
EFFICIENCY OF STMIK HANG TUAH PEKANBARU STATIONERY INVENTORY OFFICE USING MONTE CARLO METHOD
}

\author{
Rian Ordila \\ STMIK Hang Tuah Pekanbaru \\ Universitas Putra Indonesia YPTK \\ rian.68x@gmail.com
}

\begin{abstract}
Inventory management in Office Stationery needs (ATK) is instrumental in supporting administrative activities. Not terinvetaris well, resulting in the use of goods is not optimal and increase spending on this ATK. For that required a system that can manage this ATK supplies. so that in the prediction of ATK inventory can coordinate and minimize expenditure of STMIK Hang Tuah Pekanbaru expenditure. The data obtained in this research is ATK At High School of Information and Computer Management (STMIK) Hang Tuah Pekanbaru sourced from Head of Equipment Section such as paper type A4 and F4, Paperclip, Map and Printer Ink. ATK is always experiencing shortage or also excess needs. With the Monte Carlo Method, STMIK Hang Tuah Pekanbaru will be able to determine the Pattern of ATK Supplies requirement in STMIK Hang Tuah Pekanbaru and the method can give a decision in determining the pattern of ATK request that will be requested to the employee. The result of the experiment of this method is to obtain the average number of procurement requests and the average number of procurement. Estimates of the Monte Carlo simulation strategic plan that has been done will yield an estimated information on the average amount of procurement as 16 packs and the estimated average monthly expenditure of Rp. 21,333.- With the amount of calculations obtained then the Office Stationery to be purchased can be estimated and inventory can be provided to meet the demand for campus needs in 2018.
\end{abstract}

Keywords: Monte Carlo Method, Simulation, Stationery.

\section{INTRODUCTION}

Administration is an activity of planning, serving, organizing and recording a report in an organization, one of the supporters in these resources is the need for office stationery, in fact often there is a stock vacuum when needed. therefore management is needed in the form of forecasting simulation. one method often used is monte carlo method(Fadjar, 2011).

Monte Carlo method is applied by using random numbers results of reports or previous reports that are the source of the data. This random process is included in a probabilistic distribution of data variables obtained from previous data results and theoretical probabilistic distributions. The random numbers are functioned to provide information on random events at certain periods of random variables and in a structured manner following the evolution that occurs in the simulation process(Aulia, et. al., 2017).

Monte Carlo Method expected to be able to manage Inventories to predict the needs that will occur, then the output produced by the Simulation is taken into consideration to determine what inventory is budgeted in that case so that it can be seen Influence in its Application for STMIK Hang Tuah Pekanbaru. Monte Carlo is a newly developed approach that greatly reduces computing costs by performing most simulations with low accuracy at low cost, with few simulations done with high accuracy and high cost(Kirana \& D, 2017)

\section{LITERATURE REVIEW}

Simulation is a quantitative procedure, which describes a system by developing a model of the system and conducting a series of trials to estimate the behavior of the system at a certain time. Another definition, simulation is the process of designing a model (mathematics or logic) of a system and then explaining it to describe, explain, and predict (predict) the behavior (dynamic characteristics) of the system.

Simulation is not an optimization tool that gives a decision result, but only a decision support tool (decision support system). Simulation Purpose: It is expected to learn a system by imitating (to simulate) the behavior of the system so that it can solve the problems contained in the system(Suryani, 2006). 
Monte Carlo simulation is also known as Sampling Simulation or Monte Carlo Sampling technique. This simulation uses existing data (historical data) that is actually used in the simulation for other purposes. This Monte Carlo simulation method is quite simple in describing or solving problems, including in using the program on a computer(Hutahaean, 2018).

From the results of previous studies simulations using the method of Monte Carlo in the probabilistic condition of inventory management mainly determined by the arrival of orders, the size of orders, and the waiting time of orders that are uncontrolable; To overcome this, the use of simulation techniques to describe probabilistic situations in the long run has proven to be quite effective(Pratomo, 2018).

Monte Carlo is a method for repeatedly evaluating a deterministic model using a set of random numbers as input. This method is often used when the model is complex, non-linear, or involves many specific parameters that are interconnected (Kamandang, et. al., 2014).

Make a simulation of a series of experiments. The development of monte carlo simulation models is based on the probability obtained from historical data of an event and its frequency. With the formula:

$\mathrm{Pi}=\mathrm{fi} / \mathrm{n}$

Information :

Pi: Probability of occurrence i

fi: Frequency of occurrence i

$\mathrm{n}$ : Number of frequencies for all occurrences

In studying probability, there are three key words that must be known, namely experimentation, outcome (outcome) and event or event (even). For example, an experiment was conducted by asking 100 readers whether they would take statistics or calculus. From this experiment there will be several possible outcomes. For example the possibility of the first result is that as many as 58 people will take any course. Another possible outcome is that 75 people took calculus courses and the rest took statistics courses. Another example of an experiment is throwing a dice. The outcome (outcome) of throwing a dice is likely to come out one seed or two seeds or three seeds and so on. This collection of results is known as an event.

Office equipment is very important, without these tools our work will be neglected and will not even be completed so that the administrative process will be disrupted in terms of time and needs(Hamzah, et. al., 2018). Office stationery (ATK) in the field of education is used by students to work on national examinations. Students use one type of office stationery, 2B pencil. Office stationery (ATK) is often an unexpected requirement to be purchased. Office stationery (ATK) is often found at a photocopy place, at a photocopy site there are types of office stationery (ATK) such as paper, pencils, $\mathrm{x}$-type ballpoint pens, rulers and so on(Indriani \& Sudarmadi, 2015).

\section{RESEARCH METHOD}

\section{Planning}

In the development used in this study, the Alessi and Trollip (Resti) models are then used with the actual research objectives and conditions. The research phase is divided into three stages, namely 1) Planning Phase and 2) Procurement Phase. Furthermore, the application of research and development carried out consists of 5 steps as shown in Figure 1.

This section contains a complete and detailed description of the steps undertaken in conducting of research. In addition, the research step also needs to be shown in the form of flowchart of research or framework step in complete and detailed including reflected algorithm, rule, modeling, design and others related to system design aspect. 


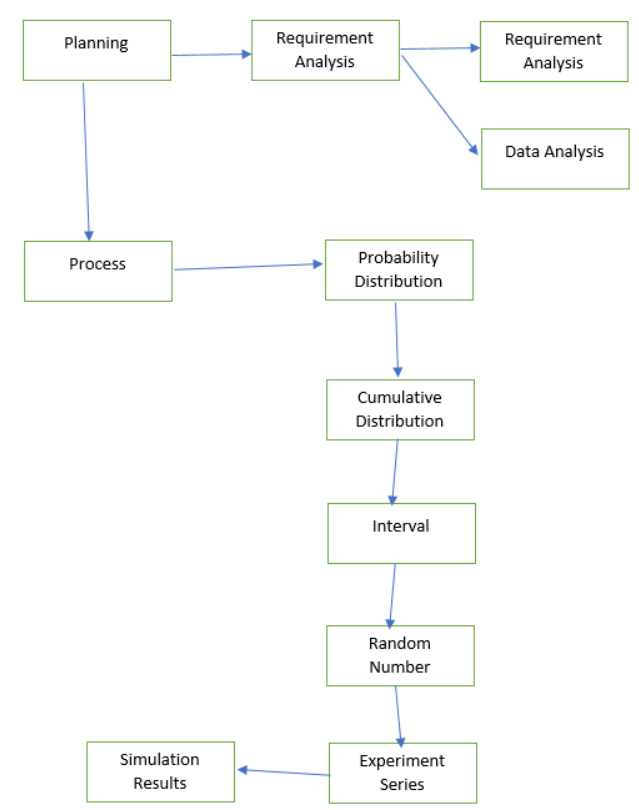

Figure 1. Development of the Alessi and Trollip Process.

\section{Process}

After the process of using the method is done, the next step is to determine the Monte Carlo Simulation with the existing 5 steps.

1. Define or determine the probability distribution for important variables.

2. Calculate the cumulative distribution for each variable in step 1.

3. Define an interval of random numbers (random numbers) for each interval.

4. Generating random numbers (Generating Random Numbers) By using a congruent mixed method (mixed congruent method).

Formula for Generate Random Numbers
a. Mixed Congruent Method

b. Multiplicative Method

5. Simulate a series of experiments by connecting random numbers with random number intervals.

\section{Data Processing with Design Algorithms}

In this study the authors implemented a test model of the results of system design using computer aids with Windows operating systems and applications using the PHP language.

\section{RESEARCH RESULTS AND DISCUSSION}

Office Stationery Supplies must be predicted according to the desired target. The target intended by STMIK Hang Tuah Pekanbaru is the achievement of the estimated average demand with supplies. To predict the average number of sales per year and the average amount of income the following year. Therefore it is necessary to calculate the monte carlo algorithm to conduct a series of experiments of generating random numbers (Generating Random Numbers), so as to get good results as expected Table 1

Table 1 - Envelope Request.

\begin{tabular}{|c|c|c|c|c|c|c|c|c|c|c|c|c|c|}
\hline \multirow{2}{*}{ Name Stationery } & \multirow{2}{*}{$\mathrm{Rp}$} & \multicolumn{10}{|c|}{ Year 2017} \\
\cline { 3 - 13 } & & 1 & 2 & 3 & 4 & 5 & 6 & 7 & 8 & 9 & 10 & 11 & 12 \\
\hline Envelope & 60.000 & 0 & 0 & 0 & 4 & 0 & 0 & 0 & 2 & 0 & 0 & 1 & 0 \\
& & & & 10 & & 10 & & 10 & &
\end{tabular}

The data above is a recapitulation of the number of procurement for the last 12 months from January to December 2017. 
To calculate the average number of customers and purchases, purchases in 2018 will come using the monte carlo method, so using the above data before processing requires a procurement price list and ATK code table 2.

Table 2 - ATK Price List Table and ATK Code.

\begin{tabular}{rcrr}
\hline Code & $\begin{array}{c}\text { Name } \\
\text { Stationery }\end{array}$ & Qty & Price \\
\hline ATK001 & Amplop & Kotak & 16.000 \\
\hline
\end{tabular}

Table 3 - ATK Price List Table and ATK Code.

\begin{tabular}{cc}
\hline Procurement & Procurement Frequency \\
\hline 0 & 4 \\
1 & 3 \\
2 & 3 \\
3 & 2 \\
\hline
\end{tabular}

Inventory simulation frameworks that use the monte carlo method can be used to examine the results in the form of an alternative of how much to procure and when to repurchase to meet the ATK inventory.

From that state, it changes the situation into a distribution of possibilities (if we assume the level of previous purchases will persist into the future) by dividing each demand by total demand. As in table 4:

Table 4 - Envelope Request.

\begin{tabular}{cc}
\hline Request Variable & $\begin{array}{c}\text { Possible } \\
\text { Occurrence }\end{array}$ \\
\hline 0 & $4 / 12=0,33$ \\
1 & $3 / 12=0,25$ \\
2 & $3 / 12=0,25$ \\
3 & $2 / 12=0,17$ \\
\hline & $12 / 12=1.00$ \\
\hline
\end{tabular}

$$
\begin{aligned}
& \text { ATK001 } \\
& \operatorname{Ke} 1=9 / 12=0,75 \\
& \operatorname{Ke} 2=1 / 12=0,08 \\
& \operatorname{Ke} 3=1 / 12=0,08 \\
& \operatorname{Ke} 4=1 / 12=0,08 \\
& \text { Total } 0,75+0,08+0,08+0,08=1
\end{aligned}
$$

Establish a cumulative probability distribution for each of the first stage variables. By doing the conversion from the usual likelihood distribution, as in the right column of table 2 to the cumulative distribution is done by adding each likelihood number to the previous number as in table 5.

Table 4 - Envelope Request.

\begin{tabular}{ccc}
\hline $\begin{array}{c}\text { Request } \\
\text { Variable }\end{array}$ & $\begin{array}{c}\text { Possible } \\
\text { Occurrence }\end{array}$ & $\begin{array}{c}\text { Cumulative } \\
\text { Possibilities }\end{array}$ \\
\hline 0 & $4 / 12=0,33$ & 0,33 \\
1 & $3 / 12=0,25$ & 0,58 \\
2 & $3 / 12=0,25$ & 0,83 \\
3 & $2 / 12=0,17$ & 1,00 \\
\hline
\end{tabular}
ATK001
$\operatorname{Ke} 1=4 / 12=0,33$
$\operatorname{Ke} 2=3 / 12=0,25$
Ke $3=3 / 12=0,25$ 
$\operatorname{Ke} 4=2 / 12=0,17$

Total $0,33+0,25+0,25+0,17=1$

After we determine the cumulative probability or what is commonly called the cumulative probability for each variable included in the simulation, then we must determine the free number that represents each possibility that has been generated. it is aimed at random number intervals. Starting from 0 to the limit of the first variable, and so on. Interval determination is based on cumulative probability.

Tabel 6. Determination of Random Number Intervals

\begin{tabular}{cccc}
\hline $\begin{array}{c}\text { Request } \\
\text { Variable }\end{array}$ & $\begin{array}{c}\text { Possible } \\
\text { Occurrence }\end{array}$ & $\begin{array}{c}\text { Cumulative } \\
\text { Possibilities }\end{array}$ & $\begin{array}{c}\text { Random Number } \\
\text { Interval }\end{array}$ \\
\hline 0 & $4 / 12=0,33$ & 0,33 & $0 \mathrm{~s} / \mathrm{d} \mathrm{32}$ \\
1 & $3 / 12=0,25$ & 0,58 & $33 \mathrm{~s} / \mathrm{d} 57$ \\
2 & $3 / 12=0,25$ & 0,83 & $58 \mathrm{~s} / \mathrm{d} 82$ \\
3 & $2 / 12=0,17$ & 1,00 & $83 \mathrm{~s} / \mathrm{d} 100$ \\
\hline
\end{tabular}

$$
\begin{aligned}
& \text { ATK001 } \\
& \begin{aligned}
\text { Ke } 1= & 00 \mathrm{~s} / \mathrm{d}(0,33 * 100)-1 \\
& =00-32 \\
\operatorname{Ke} 2= & 32+1 \mathrm{~s} / \mathrm{d}(0,58 * 100)-1 \\
& =33-57 \\
\operatorname{Ke} 3= & 57+1 \mathrm{~s} / \mathrm{d}(83 * 100)-1 \\
& =58-82 \\
\operatorname{Ke} 4= & 82+1 \mathrm{~s} / \mathrm{d}(1 * 100)-1 \\
= & 83-99
\end{aligned}
\end{aligned}
$$

Determining Random Numbers, Researchers Determine a, c, $\mathrm{m}$ and $\mathrm{z}$ with the provisions of numbers determined by prime numbers, with the following criteria

$\mathrm{Z}=$ is the first certain free number.

$\mathrm{a}=$ is the first number that is free with separate provisions.

$\mathrm{c}=$ is a free number but there is no specific relationship with $\mathrm{m}$.

$\mathrm{m}=$ set with 99 .

It is known: $\mathrm{a}=2, \mathrm{c}=23, \mathrm{~m}=99$, and $\mathrm{Zo}=22$ with a Twelve (12) month simulation forecast, with experiments with the Random Number results in the following table 7:

Finding Value $(\mathrm{a} . \mathrm{Zi}+\mathrm{c})$

Look for values for the first month from $(\mathrm{a} . \mathrm{Zi}+\mathrm{c})$

$$
\begin{aligned}
& =(\mathrm{a} . \mathrm{Zi}+\mathrm{c}) \\
& =(2 * 22)+23 \\
& =67
\end{aligned}
$$

Look for values for the second month from $(\mathrm{a} . \mathrm{Zi}+\mathrm{c})$

$$
\begin{aligned}
& =(\mathrm{a} . \mathrm{Zi}+\mathrm{c}) \\
& =(2 * 67)+23 \\
& =157
\end{aligned}
$$

Look for values for the third month from $(\mathrm{a} \cdot \mathrm{Zi}+\mathrm{c})$

$$
\begin{aligned}
& =(\mathrm{a} . \mathrm{Zi}+\mathrm{c}) \\
& =(2 * 58)+23 \\
& =139
\end{aligned}
$$

Look for values for the fourth month from $(\mathrm{a} . \mathrm{Zi}+\mathrm{c})$

$$
\begin{aligned}
& =(\mathrm{a} . \mathrm{Zi}+\mathrm{c}) \\
& =(2 * 40)+23 \\
& =103
\end{aligned}
$$

Look for values for the fifth month from $(\mathrm{a} . \mathrm{Zi}+\mathrm{c})$

$$
\begin{aligned}
& =(\mathrm{a} . \mathrm{Zi}+\mathrm{c}) \\
& =(2 * 4)+23 \\
& =31
\end{aligned}
$$

Look for values for the sixth month from $(\mathrm{a} . \mathrm{Zi}+\mathrm{c})$ 


$$
\begin{aligned}
& =(\mathrm{a} . \mathrm{Zi}+\mathrm{c}) \\
& =(2 * 31)+23 \\
& =85
\end{aligned}
$$

Look for values for the seventh month from $(\mathrm{a} . \mathrm{Zi}+\mathrm{c})$

$$
\begin{aligned}
& =(\mathrm{a} . \mathrm{Zi}+\mathrm{c}) \\
& =(2 * 85)+23 \\
& =193
\end{aligned}
$$

Look for value for the eighth month from $(\mathrm{a} . \mathrm{Zi}+\mathrm{c})$

$$
\begin{aligned}
& =(\mathrm{a} . \mathrm{Zi}+\mathrm{c}) \\
& =(2 * 94)+23 \\
& =211
\end{aligned}
$$

Look for value for the ninth month from $(\mathrm{a} . \mathrm{Zi}+\mathrm{c})$

$$
\begin{aligned}
& =(\mathrm{a} \cdot \mathrm{Zi}+\mathrm{c}) \\
& =(2 * 13)+23 \\
& =49
\end{aligned}
$$

Look for value for the tenth month from $(\mathrm{a} . \mathrm{Zi}+\mathrm{c})$

$$
\begin{aligned}
& =(\mathrm{a} . \mathrm{Zi}+\mathrm{c}) \\
& =(2 * 49)+23 \\
& =121
\end{aligned}
$$

Look for value for the eleventh month from $(\mathrm{a} . \mathrm{Zi}+\mathrm{c})$

$$
\begin{aligned}
& =(\mathrm{a} . \mathrm{Zi}+\mathrm{c}) \\
& =(2 * 22)+23 \\
& =67
\end{aligned}
$$

Look for values for the twelfth month of $(\mathrm{a} . \mathrm{Zi}+\mathrm{c})$

$$
=(\mathrm{a} . \mathrm{Zi}+\mathrm{c})
$$$$
=(2 * 67)+23
$$$$
=157
$$

Look for Value $\mathrm{Zi}+1=(\mathrm{a} . \mathrm{Zi}+\mathrm{c}) \bmod \mathrm{m}$

Look for the value $\mathrm{Zi}+1=(\mathrm{a} . \mathrm{Zi}+\mathrm{c}) \bmod \mathrm{m}$ (for the first month) $=67 \bmod 99$

$=67$

Look for the value $\mathrm{Zi}+1=(\mathrm{a} \cdot \mathrm{Zi}+\mathrm{c}) \bmod \mathrm{m}$ (for the second month)

$$
\begin{aligned}
& =157 \bmod 99 \\
& =58
\end{aligned}
$$

Look for the value $\mathrm{Zi}+1=(\mathrm{a} . \mathrm{Zi}+\mathrm{c}) \bmod \mathrm{m}$ (for the third month)

$$
\begin{aligned}
& =139 \bmod 99 \\
& =40
\end{aligned}
$$

Look for the value $\mathrm{Zi}+1=(\mathrm{a} \cdot \mathrm{Zi}+\mathrm{c}) \bmod \mathrm{m}$ (for the fourth month)

$$
\begin{aligned}
& =103 \bmod 99 \\
& =4
\end{aligned}
$$

Look for the value $\mathrm{Zi}+1=(\mathrm{a} . \mathrm{Zi}+\mathrm{c}) \bmod \mathrm{m}$ (for the fifth month)

$$
\begin{aligned}
& =31 \bmod 99 \\
& =31
\end{aligned}
$$

Look for the value $\mathrm{Zi}+1=(\mathrm{a} \cdot \mathrm{Zi}+\mathrm{c}) \bmod \mathrm{m}$ (for the sixth month)

$$
=85 \bmod 99
$$$$
=71
$$

Look for the value $\mathrm{Zi}+1=(\mathrm{a} \cdot \mathrm{Zi}+\mathrm{c}) \bmod \mathrm{m}$ (for the seventh month)

$$
\begin{aligned}
& =193 \bmod 99 \\
& =94
\end{aligned}
$$

Look for the value $\mathrm{Zi}+1=(\mathrm{a} . \mathrm{Zi}+\mathrm{c}) \bmod \mathrm{m}$ (for the eighth month)

$$
=211 \bmod 99
$$$$
=13
$$ 
Look for the value $\mathrm{Zi}+1=(\mathrm{a} \cdot \mathrm{Zi}+\mathrm{c}) \bmod \mathrm{m}$ (for the ninth month) $=49 \bmod 99$

$=49$

Look for the value $\mathrm{Zi}+1=(\mathrm{a} . \mathrm{Zi}+\mathrm{c}) \bmod \mathrm{m}$ (for the tenth month)

$=121 \bmod 99$

$=22$

Look for the value $\mathrm{Zi}+1=(\mathrm{a} . \mathrm{Zi}+\mathrm{c})$ mod $\mathrm{m}$ (for the eleventh month)

$=67 \bmod 99$

$=67$

Look for the value $\mathrm{Zi}+1=(\mathrm{a} . \mathrm{Zi}+\mathrm{c}) \bmod \mathrm{m}$ (for the twelfth month)

$=157 \bmod 99$

$=58$

Tabel 7. Random Number Results

\begin{tabular}{cccc}
\hline $\mathrm{I}$ & $\mathrm{Zi}$ & $\mathrm{a} . \mathrm{Zi}+\mathrm{c}$ & $\mathrm{i}+1=(\mathrm{a} . \mathrm{Zi}+\mathrm{c}) \bmod \mathrm{m}$ \\
\hline 0 & 22 & 67 & 67 \\
1 & 67 & 157 & 58 \\
2 & 58 & 139 & 40 \\
3 & 40 & 103 & 4 \\
4 & 4 & 31 & 31 \\
5 & 31 & 85 & 85 \\
6 & 85 & 193 & 94 \\
7 & 94 & 211 & 13 \\
8 & 13 & 49 & 49 \\
9 & 49 & 121 & 22 \\
10 & 22 & 67 & 67 \\
11 & 67 & 157 & 58 \\
12 & 58 & 139 & 40 \\
\hline
\end{tabular}

After carrying out the Distribution of Possibilities, it is matched with the random number interval Analysis Experiment Results in table 8.

Tabel 8. Possible Distribution

\begin{tabular}{rcc}
\hline Month & Random Number & Demand Envelope \\
\hline 1 & 67 & 2 \\
2 & 58 & 2 \\
3 & 40 & 1 \\
4 & 4 & 0 \\
5 & 31 & 0 \\
6 & 85 & 3 \\
7 & 94 & 3 \\
8 & 13 & 0 \\
9 & 49 & 1 \\
10 & 22 & 0 \\
11 & 67 & 2 \\
12 & 58 & 2 \\
\hline
\end{tabular}

At ATK001 i.e. Envelope with a Price of Rp. 16,000 / Box. With Total Demand for 12 months is $2+2+1+0+0+3+3+0+1+0+2+2=16$. Average Request per month is $16 / 12$ Months $=1.3$

Total Expenditures for 12 months is Rp. 16,000 x 12 Months = Rp. 256,000. The total envelope demand for 12 months is 16 boxes, with an average demand per month of 1.3 boxes.

Tabel 9. Simulation of Procurement Average

\begin{tabular}{lllll}
\hline Code & Name & Qty & Price & Total \\
\hline
\end{tabular}




\begin{tabular}{|c|c|c|c|c|}
\hline \multicolumn{5}{|c|}{ ATK } \\
\hline ATK001 & Envelope & 16 & $\underset{16.000}{R p}$ & $\operatorname{Rp} 256.000$ \\
\hline Per Month & & 1.3 & & Rp 21.333 \\
\hline
\end{tabular}

Then the simulation of the procurement of Office Stationery at the Hang Tuah Pekanbaru STMIK obtained based on a series of experiments, namely the average number of 16 Envelope Envelopes procurement and for the average Purchase of Envelopes of Rp 21,333 so that the total purchase of ATK in 2018 Rp. 256,000.

\section{CONCLUSIONS}

From the tests conducted on the results of the evaluation of procurement management simulations using the Monte Carlo Method, the results obtained are in accordance with the manual calculations that have been carried out. the use of simulations to illustrate probabilistic situations in the long run proves to be quite effective. probabilistic in the long run proves to be quite effective.

Prediction and Simulation which are implemented using a system that is made is considered ready and recommended so as to be able to solve the problem of predicting the needs of the Office Stationery because the predicted results are considered to be probabilities. His influence on the application of the Monte Carlo Method can provide more efficient results and lower budget pressures over the next 1 year.

\section{REFERENCES}

Aulia, N. F., Mesran \& Silalahi, N. (2017). Simulasi Persediaan Barang Pada Koperasi Dengan Menggunakan Metode Monte Carlo (Studi Kasus : Sejahtera Mandiri Tamora). Jurnal INFOTEK, 2(1): 49-48.

Fadjar, A. (2011). Aplikasi Simulasi Monte Carlo Dalam Estimasi Biaya Proyek. SMARTek, 6(4).

Hamzah, M. L., Rusilawati, E., \& Purwati, A. A. (2018). Sistem Aplikasi Sarana Prasarana Perguruan Tinggi Menggunakan Teknologi Near Field Communication Berbasis Android. Intecoms: Journal of Information Technology and Computer Science, 1(2), 251-261.

Hutahaean, H. D. (2018). Analisa Simulasi Monte Carlo Untuk Memprediksi Tingkat Kehadiran mahasiswa Dalam Perkuliahan (Studi Kasus: STMIK Pelita Nusantara). Journal Of Informatic Pelita Nusantara, 3(1).

Indriani, K., \& Sudarmadi, S. (2015). Sistem Informasi Inventory Alat Tulis Kantor (Atk) Menggunakan Metode Waterfall (Studi Kasus: Otoritas Jasa Keuangan (Ojk)). Jurnal Techno Nusa Mandiri, 12(1), 69-76.

Kamandang, Z. R., Unas, S. E., \& Negara, K. P. (2014). Penilaian Risiko Finansial Dengan Menggunakan Simulasi Monte Carlo (Studi Kasus Gedung STIKES Maharani Malang). Jurnal Mahasiswa Jurusan Teknik Sipil, 1(2), 286.

Kirana, M. C., \& D, D. (2017). Simulasi Pengendalian Bahan Baku Produksi Menggunakan Metode Monte Carlo danExponensial (Studi Kasus : PT. XYZ). Energy Jurnal Ilmiah Ilmu-ilmu Teknik, 7(1).

Pratomo, E. W. (2018). Analisis proyeksi jumlah permintaan dan jumlah perencanaan persediaan produk susu dengan simulasi monte carlo pada cv milkindo berka abadi kepanjen (Doctoral dissertation, POLITEKNIK NEGERI MALANG).

Suryani, E. (2006). Permodelan dan Simulasi. Edisi Pertama. Yogyakarta. Graha Ilmu. 